\title{
The Emergence of The Autonomous Individual
}

\section{Hyacinth Pink}

Abstract: This research article titled "The Emergence of the Autonomous Individual "explores the early fiction of Ayn Rand and Chinua Achebe and proceeds with the assumption that the autonomous individual is seen emerging in Ayn Rand's We the Living (1936) and Anthem (1938) and in Chinua Achebe's Things Fall Apart (1958) and Arrow of God (1964) respectively. In the fiction of Ayn Rand, the researcher explores the nature of the individual from the socio-political context. Rand's Anthem follows We the Living chronologically, and is set in Communist Russia and trigger off the rise of the individual. Though Chinua Achebe's Arrow of God does not follow Things Fall Apart chronologically, these two novels are set in the Ibo tradition and spark off the beginnings of the quest for the individual. Both Rand and Achebe have been brought together for this study as each author supports to a very large extent, the opposite poles of the hypothesis which, is:

Whether the sphere of moral and imaginative values by which an individual functions in society is at once autonomous or related to society.

The hypothesis is analyzed in three phases here .Each phase demonstrates the different stages in the growth and development of 'individualism.' This is discussed against the background of the different texts chosen for each phase. This article attempts to specifically portray the struggle of four protagonists, namely (Kira Arugounova of We The Living, Equality 7-2521 of Anthem, Okonkwo of Things Fall Apart and Ezeulu of Arrow of God) against two different kinds of claustrophobic societies: Rand's Communistic Society of Soviet Russia and Achebe's Ibo Society of Nigeria, both of which smother the life of the individual. Both Rand's and Achebe's novels highlight the theme of "The Emergence of the Autonomous Individual." Rand's individuals who struggle to assert their individuality in this phase are Kira Argounova, Leo Kovalensky and Comrade Andrei Taganova of We the Living; Equality 7-2521 and Liberty 5-3000 of Anthem; Okonkwo and Nwoye of Things Fall Apart and Ezeulu of Arrow of God respectively. These individuals suffer and struggle, but their cause and manner of struggle vary. While Rand's protagonists attempts to break the fetters of Communism to which they are tied and liberate themselves to individual freedom, happiness and self fulfillment; Achebe's individuals, in this phase, struggle to maintain the dignity of their own Ibo society, which the white man ignorantly attempts to destroy. Though both the societies represent the collective, they are absolutely contrastive in nature. But both the societies are common in their functioning, in the sense, that both societies control the lives and activity of the individuals to a large extent. Kira Argounova and Leo Kovalensky of We The Living and Equality 7-2521 and Liberty 5-3000 of Anthem are portrayed struggling to combat the terrible tyranny of a paralyzing, dictatorial state on the one hand; while Okonkowo of Things Fall Apart and Ezeulu of Arrow of God are trying to break away from a traditional-communal bound ethos, and assert their own individuality on the other.

Manuscript received on June 15, 2019.

Revised Manuscript received on June 25, 2019.

Manuscript published on July 30, 2019.

* Correspondence Author

Dr. Hyacinth Pink*, Professor \& Head, Department of English, Kumaraguru College of Technology, Chinnavedampatti, Coimbatore (Tamil Nadu), India. E-mail: hyacinthpink.sci@kct.ac.in

(C) The Authors. Published by Blue Eyes Intelligence Engineering and Sciences Publication (BEIESP). This is an open access article under the CC BY-NC-ND license (http://creativecommons.org/licenses/by-nc-nd/4.0/)

\section{INTRODUCTION}

This research article titled "The Emergence of the Autonomous Individual "explores the early fiction of Ayn Rand and Chinua Achebe and proceeds with the assumption that the autonomous individual is seen emerging in Ayn Rand's We the Living (1936) and Anthem (1938) and in Chinua Achebe's Things Fall Apart (1958) and Arrow of God (1964) respectively. In the fiction of Ayn Rand, the researcher explores the nature of the individual from the socio-political context. Rand's Anthem follows We the Living chronologically, and is set in Communist Russia and trigger off the rise of the individual. Though Chinua Achebe's Arrow of God does not follow Things Fall Apart chronologically, these two novels are set in the Ibo tradition and spark off the beginnings of the quest for the individual.

Both Rand and Achebe have been brought together for this study as each author supports to a very large extent, the opposite poles of the hypothesis which, is:

Whether the sphere of moral and imaginative values by which an individual functions in society is at once autonomous or related to society.

The hypothesis is analyzed in three phases here .Each phase demonstrates the different stages in the growth and development of 'individualism.' This is discussed against the background of the different texts chosen for each phase.

This article attempts to portray the struggle of four protagonists, (Kira Arugounova of We The Living, Equality 7-2521 of Anthem, Okonkwo of Things Fall Apart and Ezeulu of Arrow of God) against two different kinds of claustrophobic societies: Rand's Communistic Society of Soviet Russia and Achebe's Ibo Society of Nigeria, both of which smother the life of the individual. Both Rand's and Achebe's novels mentioned above highlight the theme of "The Emergence of the Autonomous Individual." Rand's individuals who struggle to assert their individuality in this phase are Kira Argounova, Leo Kovalensky and Comrade Andrei Taganova of We the Living; Equality 7-2521 and Liberty 5-3000 of Anthem; Okonkwo and Nwoye of Things Fall Apart and Ezeulu of Arrow of God respectively. These individuals suffer and struggle, but their cause and manner of struggle vary. While Rand's protagonists attempts to break the fetters of Communism to which they are tied and liberate themselves to individual freedom, happiness and self fulfillment; Achebe's individuals, in this phase, struggle to maintain the dignity of their own Ibo society, which the white man ignorantly attempts to destroy. Though both the societies represent the collective, they are absolutely contrastive in nature.

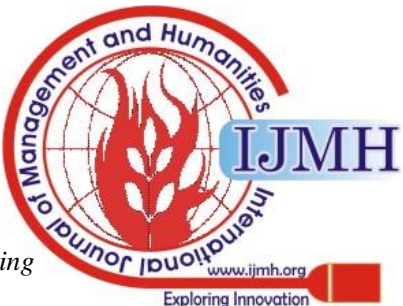




\section{The Emergence of The Autonomous Individual}

In Rand's world, it is the traditional communist society of Russia; in Achebe it is a well-knit meaningful communal society. But both the societies are common in their functioning, in the sense, that both societies control the lives and activity of the individuals to a large extent. Kira Argounova and Leo Kovalensky of

We The Living and Equality 7-2521 and Liberty 5-3000 of Anthem are portrayed struggling to combat the terrible tyranny of a paralyzing, dictatorial state on the one hand; while Okonkowo of Things Fall Apart and Ezeulu of Arrow of God are trying to break away from a traditionalcommunal bound ethos, and assert their own individuality on the other.

We the Living and Anthem depict the struggle of 'Man against the State. Both these novels depict the story of "a ruthless, blazing and courageous love, a love that flung defiance against the scavengers of human souls".(WTL5) In this bitter struggle of the individual against 'The State', five people stand out with the mark of the unconquered in their bearing. Kira Arugounova, the heroic protagonist in We The Living and the two men who love her, comrade Andrei Taganov,"the reddest communist"(WTL9) and Leo Kovalensky, an aristocrat and Kira's" top value" ; and the heroic protagonist in Anthem, Equality 7-2521, "a man of intransigent mind"(A7) and Liberty 5-3000, "The Golden One (A9) "whom he chose to love". In these intensely dramatic stories, Rand portrays what the theories of Communism mean in practice. We The Living and Anthem are stories, not of politics, but of men and women who struggle for existence behind the Red Banners and Slogans and hence condemn the supremacy of any State or Society over the individual consciousness. Rand, in her article "The Totalitarian Universe" observes: A society that robs an individual of the product of his effort or enslaves him or attempts to limit the freedom of his mind, is not a society, but a mob, held together by institutionalized gang rule. ${ }^{1}$ (Qtd in. The Ominous Parallels, 1982:26)

In We the Living, Rand uses Kira Argounova as her mouth piece when she philosophizes on the vague abstraction society: "If you write a whole line of zeros, it's still nothing". (WT 633)While Rand obviously champions the cause of the 'individual will', Achebe's emphasizes the collective will when he asserts in Things Fall Part: "Where something stands, something else should stand beside it". (TFA21) Rand's and Achebe's objectives in writing naturally evolve from their different experiences and convictions. While Rand writes with Russia in her bones, Achebe evolves as a more detached and objective artist. But unlike Achebe, Rand, born Alice Rosenbaun, a Jew, leaves behind her a blood-soaked dictatorship, the soul-shriveling terror of a life without hope or future, and marches into the United States, boiling with energy and limitless ambition.

The rush to Collectivism had begun in America which earned the thirties, the titles of 'The Red decade'. Barbara Branden in The Passion of Ayn Rand quotes Granville Hicks, the literary terrorist of the Left who writes in the prestigious New Masses: "To be a good writer, a man must first become a good communist". ${ }^{2}$ ( Branden 1986:71) Dorothy Parker announces: "There is no longer I", there is only "we". "The day of the individual is dead."3 (Ibidem: 77) Rand now realizes the enormity of what has to be

fought. And so in 1930, Rand begins outlining her first novel. Its working title was "Air Tight", later changed to We the Living. In We The Living Rand attempts to tell the world, the nature of her Russian nightmare; "that Russia was a huge cemetery and that people were slowly dying". (WTL 6) We the Living was a protest, Rand later said, and an introduction to her philosophy - Individualism versus Collectivism. Rand shows that Collectivism destroys not only the average man but most particularly the best among men - those with the greatest gifts to offer the world. "We the Living got Russia out of my system", Rand said. "By the time the book was finished, the issue of Russia was also finished for me". ${ }^{4}$ (Branden 1986:78) The Alice Rosenbaun of Soviet Russia dies and like phoenix from her own ashes is born the Ayn Rand of America. We the Living and Anthem function as a kind of catharsis for Rand. Things Fall Apart and Arrow of God demonstrate nostalgia for Achebe. Achebe, in a 1964 lecture on "The Role of the Writer in a New Nation" speaks of "a strong temptation to idealize the African past to extol its good points and pretend the bad never existed." 5 (Achebe 1964:67) To a certain extent, Rand and Achebe are literally reliving their Russian and Nigerian experiences. In both We the Living and Anthem, Rand explores the theme: 'The sanctity of human life.' The word 'sanctity' is used not in the mystical sense as Rand tells us in the 'Introduction' to We the Living, (WTLvii) but in the essence of 'supreme value'. In the 'Foreword' to We the Living Rand makes explicit her theme: The essence of my theme is contained in the words of Irina, a minor character of the story, a young girl who is sentenced to imprisonment in Siberia and knows that she will never return: "There's something that I would like to understand. And I don't think anyone can explain it. There's your life. You begin it feeling that it's so precious and rare, so beautiful that it's like a sacred treasure. Now it's over and it doesn't make a difference to anyone, and it isn't that they are indifferent, it's just that they don't know. (WTL v)

In Atlas Shrugged, Rand's last novel, Rand reaches the full answer to Irina's question, where she explains the philosophical, psychological and moral meaning of the men who value their own lives and of the men who do not. Rand shows in Atlas Shrugged, that the men who value their own lives are the prime movers of mankind and the men who do not, are the 'social suckers' the parasites' and the 'metaphysical killers.' (VOS19) Barbara Branden, quoting Rand in The Passion of Ayn Rand observes: "In Atlas Shrugged, I show why men are motivated by a life premise or a death premise. In We The Living. I only show they are". ${ }^{6}$ (Branden 186:101)

Just as Rand has a specific aim in writing We The Living and Anthem, Achebe too in writing Things Fall Apart and Arrow of God wants, as Robert Wren tells us in Achebe's World: The Historical and Cultural Context of the Novels of Chinua Achebe:

To allow the old ways their due and to deal fairly with his ancestors, to set the scene right ....as an act of atonement with my past ... the ritual return and homage of a prodigal son.$^{7}$ (Wren 1980:3) 
In the light of this remark, Achebe's novels especially Things Fall Apart and Arrow of God become a record of: An old and deeply articulate culture too long silenced by European cultural projection depicting the realities of tribal life lost behind the innumerable accounts of African primitive customs. ${ }^{\mathbf{8}}$ (Ibidem: 15 )

Rand and Achebe explore thematically, the quest of the autonomous individual, but Achebe's concept of individuality does not permit the individual to be considered as 'supreme' or 'totally free' as Rand does. Achebe's individual is controlled by the will of the community. "No man, however, great, can win judgment against all the people". (TFA 16) But Rand treats man as an end in himself and the achievement of his own happiness as man's highest moral purpose. (VOS 21) Both Rand and Achebe's protagonists in We the Living and Anthem, Kira Argounova and Equality 7-2521 are pitched against their Russian society: The State. In We the Living, Kira Argounova the female protagonist and Equality 7-2521 of Anthem are see emerging from the terrible fangs of a totalitarian system. But unlike Equality 7-2521 who successfully himself and the sacred world "I", Kira Arugounova of We the Living is shot by Ivan Ivanov in the process of attaining freedom and self-preservation.

Achebe's protagonists Okonkwo of Things Fall Apart and Ezeulu Arrow of God are pictured struggling against a well-knit, human and meaningful Ibo society which may be stateless, but is much disciplined. Achebe's individuals are combating a communal society; Rand's individual is combating a communist society.

In the following section of this chapter of the thesis, the researcher analyses the struggle of the protagonist in each author's text. Kira Arugounova of We The Living and Equality 7-2521 of Anthem are set in the mould of future Ayn Rand protagonists, dedicated to two purposes: i) the work they had chosen to do ii) the men and women they had chosen to love. Rand's individuals are very assertive and confident of what they want to do; Achebe's individuals are victims of circumstances and of the colonial encounter, and hence the struggle is also totally different. Kira Argounova, "a young girl of eighteen, with a fierce independence, grey-eyed, a calm mouth, defiant, enraptured, and solemn" (WTL 12) plans to be an engineer, but she is the daughter of a Bourgeoisie, a class enemy and hence is expelled from the University in The Student Purge. (WTL,21) The Revolution brings pestilence, disease, poverty and starvation.In the name of the people, factories and banks are nationalized. "A flight from the city stood before them as the Argounova's only course of action." (WTL 14) Kara's first steps on Petrograd soil make her determined to fight the collective system. She scorns at banners that carried messages like "Proletarians of the World Unite". (WTL 19) "Long live the Dictatorship of the Proletariat (WTL 22) "Who is not with is, is against us", (WTL 24) "Comrades, we are the builders of a New Life". (WTL 26).To Kira, the system is rotten at the root. Kira is condemned as highly anti-social', 'lacking things of the spirit', and 'most undutiful'. (WTL 33) But Kira learns the 'Joy of being alone'. (WTL 35) She rejects young man, treackly fairly tales and religion. Her ideas, convictions, values are very different from her sister, Lydia's. They are more like Ayn Rand's herself. While Lydia, her sister, falls in love with a grand opera tenor and admires Saint Francis of Assisi the only hero who is known to Kira is a Viking is a story, "who laughed at priests and lived but for the joy and the wonder and the glory of the God that was himself". (WTL 37) The end of this legend pictures the Viking on a tour over a city he had conquered, drinking a toast "to a life which is reason unto itself" (WTL 41) Kira Argounova is a study of the exemplification of the 'self'. Kira believes in the sanctity of life; but the leaders of the Russian Revolution defines a life as "only a brick and of no use unless cemented to other bricks".(WTL 44) Kira believes that she is an end in herself; the communist society believes that man is a means to a social end. On October 7, 1933, Adolf Hitler at Brickberg rendered this theory, quoted by N.H. Baynes in his book The Speeches of Adolf Hitler:

It is thus necessary that the individual should come to realize that his own ego is of no importance in comparison with the existence of his nation; that the position of the individual ego is conditioned solely by the interests of the nation's as a whole ... that above all, the unity of a nation's spirit and will are worth far more than the freedom of the individual...9 (Baynes 1942:871-872)

Kira Argounova is symbolic of the 'individual' cause, and comrade Andrei Taganov symbolizes the 'collective'. Kira condemns 'The Party' because "it dares to touch things sacred in the best of us which no outsider should touch, be it any State, Collective or any number of millions". (WTL 80) But Comrade Taganov believes that "the millions cannot be sacrificed for the few" (Ibidem) and Kira screams:

What 'are' your masses, but millions of dull, shriveled, stagnant souls that have no thoughts of their own, no dreams of their own, no will of their own, who eat and sleep and, chew helplessly the words others put into their brains. And for those you would sacrifice the few who know life and are life. I loathe your ideals because I know no greater injustice than giving the underserved. Because men are not equal in ability and one can't treat them as if they were. (WTL 8)

'The State' Kira argues, is but a servant and a convenience for a larger number of people, just like the electric light and the plumbing system. It is absurd to claim that men exist for the plumbing and not the plumbing for the men.

And if your plumbing pipes got badly out of order, wouldn't it be preposterous to sit still and not make an effort to mend them. I hope that when you find those pipes running with your own blood-you'll still think they were worth mending (WTL 82) In the "Ethics of Evil", quoted in The Ominous Parallels, Rand refers to two opposite approaches to morality: the pro-self approach versus the anti-self approach or the ethics of egoism versus the ethics of self-sacrifice. ${ }^{10}$ (Peikoff 1982:81) While egoists hold that a man's primary moral obligation is to serve some entity outside him. Morality, writes Edgar Jung, a German Rightist, consists in the self-abandonment of the Ego, for the sake of the higher values of the State. Such is the ethical base of Collectivism, which demands of each man, a life of subservience to the whole. 


\section{The Emergence of The Autonomous Individual}

In We The Living, these two approaches of morality are well brought out through the conflict in the value-system of Rand's protagonist, Kira and those of the State. While Kira believes in the sanctity of human life, the State believes in its own sanctity. As a result of the revolution, Leo Kovalensky is about to die of Tuberculosis, but The State would not even register him, as he is not 'member of the party', (WTL 109) nor a State Employee. (WTL 121) That he is going to die meant so little to the State, which he is not registered nor a member of the Trade Union meant so little to Kira. But Leo's life has to be bought, or saved any cost. Kira tries various sources. She approaches her cousin Victor, a member of "The Party" for help. But Victor's concern and loyalty to The Party membership, "is a sacred trust not to be used for purposes of personal advantage". (WTK 211) Kira rushes to Marisha, who laughs and says: With all our sanatoriums stuffed like herring -barrels, and waiting lists till the next generation, and comrade workers rotting alive waiting - and here, he's not even sick yet. You don't realize reality, citizen Arugounova (WTL 211)

Kira makes one last plea to the State. It takes many weeks of calls, letters, introductions, secretaries and assistants, but finally she gets an appointment with one of the most powerful officials of the Petrograd Government. Kira goes to see him in person. She looks straight at him, her eyes are not hostile, nor pleading; they are clear, trusting, and serene; her voice is calm; she pleads for a life that is going to die:

They didn't write his name on a piece of paper with many other names and call it a membership. One signature of your hand and he can go to a sanatorium and he doesn't have to die. Do you know what death is, nothing at all... never again..never...no matter what we do. Do you see why he can't die? I love him. There's something in each of us something like the very heart of life condensed and that should not be touched. Well, he is 'that' to me. (WTL 216) The terror, cruelty, and inhumanity, the emptiness and hypocrisy of collectivized ethics is amply demonstrated in the response of one of the highest representative of The State: "One hundred thousand workers died in the Civil War. Why, in the face of The Union of Socialist Soviet Republic, can't one aristocrat die?" (WTL 216-217)

Leo Kovalevsky is sentenced to die. But Kira fights one last battle. She meets Comrade Taganov, and to suit her convenience, Andrei confesses his love for her: "I'd give everything I have Kira for something you can't give me" (WTL 221) Kira is not thinking of Andrei nor Leo. She was thinking of Maria Petrovna and the red bubble on her dying lips and she hears the scream: "Kira I want to live. I want to live". (WTL 219) She is not sure now whether it is Maria Petrovna or Leo screaming, she throws the words at Andrei: "I can. I love you", (WTL 223) From that night, Kira Arugounova becomes Comrade Taganov, the 'reddest Communist' is gradually seen alienating himself from the G.P.U. and the State. Andrei also realizes the double standards of his party's politics.

The State is the most senseless and useless of monsters standing in the way of human life-and that's something we call humanity's Politics. We shoot one speculator and a hundred others hire taxis on Nevsky every evening. We raise villages to the ground; we fire machine guns into the rows of peasants crazed with misery, when they kill a

communist. And ten of the avenged victim's party brother's drink champagne at the home of a man with diamond studs in his shirt. Where did he get the diamonds? Who is paying for the Champagne? We don't look into that too closely. (WTL 319)

The supreme value of the individual's life and the evils of a totalitarian State that claim the right to sacrifice it, is further brought out in the scene where Comrade Taganov learns the truth about Kira's relationship to both of them: Leo Kovalevsky, the man she loves and fights to save his life, and Andrei Taganov whom she loves but is unfaithful to. Andrei Taganov is officially designated to arrest Leo Kovalensky, for committing the political crime of opening a private food store. At the home of Leo Kovalensky, Comrade Taganov realizes that Kira is also Leo's mistress. Andrei Taganov has Leo Kovalensky locked in a cell at the G.P.U. and returns to his house where Kira decides to lay bare the truth before him and also hurl at him, the hatred and revenge she feels for a party to which Taganov has dedicated twenty eight years of his life. Kira tells Andrei: "For all the sorrows your comrades brought to a living world, at least one of them has been paid. I paid it. In you and to you". (WTL 387) Rand's satiric condemnation of the Collective is seen in her powerful description of Communism: The Party believes in the hundreds, the millions, the majority, simply because they - "stomachs, legs, hands, tongues and souls", (Ibidem) have been registered, but not Leo, since he is only an individual. "All stones are cobblestones to you. And diamonds, they're useless because they sparkle too brightly in the sun, and its too hard under the hoofs marching to the Proletarian future, and you smile and you sing hymns to the toil of the Collective". (WTL 390) It comes as a solemn army and attempts to bring new life to men, but succeeds only to tear that life knows nothing about. The party drives men into iron cellars and closes all doors, and "locks it air tight till the blood-vessels of our spirits burst. Then you stare and wonder what it is doing to us". (WTL 392)

The complete transformation of a collectivist to an individual is demonstrated in Andrei's conviction that the Red Party is a failure. In his speech at the Party Club, where Andrei's comrades are waiting for report on the agrarian situation, Andrei condemns his Communist party for their policy of the end justifying the means, especially when there is no end. He condemns the Red Party for its inhumanity and mass killings of peasants who refuse to surrender their leaders. He scorns The Party's 'great work'. (WTL 390)You consecrated warriors of a new life: Are we sure we know what we are doing. No one can tell men what they must live for. No one can take that right - because there are things in men, in the best of us which are above all states, above all collectives: Man's mind and his values. Aren't you living for yourself and only for yourself? Call it your aim, your love, your cause - isn't it still 'your' cause? Give your life, die for your ideal - isn't it still 'your' ideal? Every honest man lives for himself. The one who doesn't doesn't live at all. 
You cannot change it because that's the way man is born, alone, complete, an end in himself. No laws, no party, no G.P.U. will ever kill that thing in man which knows how to say 'I'. You cannot enslave man's mind. You can only destroy it. You have tried. Now look at what you are getting. Look at those whom you allow to triumph. Deny the best in men- and see what will survive. Do we want the crippled, creeping, crawling, broken monstrosities that we're producing? Are we not castrating life in order to perpetuate it? (WTL 392)

That communist should make a speech for the cause of the individual in a dictatorial system like Soviet Russia is to record a major shift. Comrade Andrei Taganov is one of the most remarkable of characters in We The Living. Described as ' the reddest communist, Andrei is sincere and devoted to the cause of the collective. Through love in the person of the female protagonist, Kira Argounova and her tremendous influence on him, a rapid change and growth takes place in Comrade Taganov's life. He displays great virtue and humanism and begins to realize and discover the importance of personal values. When after 'The Purge', bo the Kira and Leo are expelled from the Institute and the University respectively, it is this member of the G.P.U., Comrade Taganov, who functions as a life-saviour. Andrei's great love for Kira Arugounova makes him give her his whole salary, leaving him "only what she could spare". (WTL 264) It is Andrei's money that sent Leo Kovalensky to a tubercular sanatorium in the Crimea. It pays for the life of a man she loves long before she meets Comrade Taganov. Joseph Sobran, in his article: "Mussolini Shrugged; Ayn Rand Revived", published in the National Review, portrays Andrei as the nobler of the two men. Unlike Leo, he prefers death to dishonor. He serves Communism only as long as he can believe in it. Except in his love for Kira, he serves it incorruptibly. Leo on the other hand is willing to compromise himself. When Andrei sees the truth, he sacrifices himself for Kira as she sacrifices herself for Leo. But Leo is incapable of such love being what he is Kira never tries to explain her actions to him, rather mysteriously, she simply allows him to think the worst about her and to sink further into cynicism. ${ }^{11}$ (Sobran 1989: 53) One wonders whether she is sparing him the torment of full knowledge or whether she feels it futile to try to keep his love, and pointless to justify herself. Be that as it may, Kira loves Leo, and not the more deserving Andrei. When it comes to winning maiden's affections, the smart money still on reckless virility rather than moral rectitude, and reckless virility happens to be Leo's long suit. He tells off Soviet officials (including Andrei) with a courage that frightens Kira for him, even as makes her admire him all the more. "Andrei has his own courage, as his final Sydney Carton gesture shows, but as a G.P.U. officer, he is hardly in a position to display it: in executing his duties he simply appears ruthless". ${ }^{12}$ (Sobran 1989:52) Andrei Taganov is seen as an individual, who, in the beginning turns away from himself and seeks to be one with the social substance, thus alienating himself from his essence or particular self. After his encounter with Kira, Andrei seems to concentrate on developing his inner self and turns his back on the social substance. Andrei's life, before he meets Kira can be described in the Hegelian sense as 'a negation of personality' 13 (Hegel 1967:114) Personality developments, Hegel contends, is characterized by one's freedom to express himself freely, which Andrei initially lacks but later acquires, as portrayed in his speech on the agrarian situation.

Pavel Syerov and Victor Dunaev are also part of the collective, but unlike Andrei Taganov, they function as the most detrimental characters to human happiness. Both are not only opportunists but parasites who use people to further their own ends. Victor marries Marsha because he thinks his proletariat background will help him in the Party; when that is not, he turns in his own sister and her fiancé Irina and Sasha, for counter revolutionary activities to prove his loyalty to the Party; when he has neither loyalty nor honour in his demeanor. Pavel Syerov, a ladies' man, uses Comrade Sonia to further his Party's aim as a revolutionary. While spouting the party line, Syerov secretly backs the black market speculations of Karp Morozov and Leo Kovalensky. His party saves him when his black market dealings are uncovered; his hypocrisy continues when he uses Andrei's funeral as an opportunity for selfaggrandizement. Andrei Taganov was not a famous man, but he bore proudly and gallantly one title; that of Communist. He and I grew up together and together we shared the long years of toil; side by side we fought in the ranks of the Red Army. He is dead but his work, our work, goes on. The individual may fall, but the collective lives forever...Thousands of us are gathered here to honour one man-But one man means nothing in the face of the mighty proletarian Collective, no matter how worthy his achievements. We would not be here, if that man were not more than a single individual, if he were not to honour the birth of a new humanity, with a new race of men, with new standards. The first and basic one is the loss of a most dangerous, the most insidious, the most evil of human words- The word 'I'. We have outgrown it. 'WE' is the slogan of the future: The 'Collective' stands in our hearts where the old monster 'Self' has stood. Our only badge of honour is the consecrated unselfish service of the collective. (WTL 419) While the protagonist Kira Arugounova and the sub-protagonists Andrei Taganov and Leo Kovalensky are Rand's prime movers of mankind, Pavel Syerov and Victor Dunaev are the 'metaphysical killers' and the 'social suckers' and the 'parasites', symbolizing 'Good' and 'Evil' in life. (VOS 19) In Anthem (1936) Rand's next novelette, Rand projects this society of the future, which has accepted total collectivism with all its ultimate consequences. Men have relapsed into primitive savagery and stagnation; The Word 'I' has vanished from the human language; there are no singular pronouns; a man refers to himself as 'we' and to another as 'they'. They are conceived in 'Controlled Palaces of Mating". (WTL15) They die in "The Home of the Useless." (WTL 17) From the womb to the tomb, the crowd is one: 'A Great We', they exist only to serve The State. In all that is left of humanity, there is only one man "who dared to think, to seek and to love." (A 9) He is Equality 7-2521, "a man of intransigent mind," (A 11) who lives in the dark ages of the future.

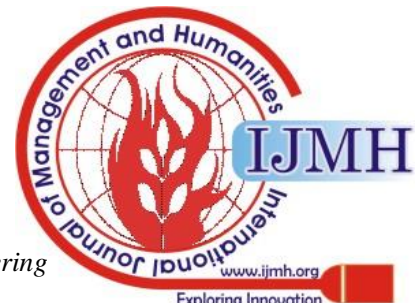




\section{The Emergence of The Autonomous Individual}

In, a loveless world he dares to love the woman of his choice, Liberty 5-3000. In an age that has lost all trace of science and civilization, he has the courage to seek after knowledge, a treacherous blasphemy. But these are not the crimes for which he would be killed. He is marked for death because he has committed and unpardonable sin; he stands our from the mindless human herd. He is a man alone, and rediscovers the lost and holy word ' $\mathrm{I}$ '.

In this novelette, Rand portrays the horrors of dictatorship where none among men may

be alone. Over the portals of the Palace of the World Council, these words of Truth are cut in

Marble:

We are one in all and all in one. There are no men but only the great We-One, indivisible and forever'. (A 14)

Each night, raising their right arms, they proclaim the pledge, along with their Teachers:

We are nothing. Mankind is all. By the grace of our brothers we are allowed our lives. We exist through, by and for our brothers, who are The State, Amen. (A 28)

Rand's heroic protagonist, Equality 7-2521 is condemned by the State as evil, and lashed because "his body had grown beyond the bodies of his brother's; (A13)he "found learning too easy, when it was considered a sin to be born with a head that was too quick ". (A 15) "he sang aloud without reason, and was guilty of the great 'Transgression of Preference' in choosing the work he liked to do;" (A 17) and "in noticing Liberty 5-3000 at a time when men and women were forbidden notice each other. (A 19) Equality 7-2521 is a thing set apart from his brothers: The Collective. With bowed heads, eyes dull, never looking at one another in the eyes, "their muscles drawn, shoulders hunched, their bodies shrinking with fear, without name, without shape they walked through the city". (A 47) Fraternity 2-5503, "a quiet boy with wise kind eyes", cries, "their bodies shaking with sobs, they cannot explain". Solidarity 9-6347, "a bright youth, fearless at day, screams in their sleep..."Help us! Help us" and the doctors cannot cure solidarity 96347.Union 5-3992,"a sickly lad with convulsions was always frothing at the mouth." (A 49) The Society here is a disease-stricken, pestilence-polluted society. The political system of such a society created psychological freaks. In contrast to this sick society, Equality 7-2521 "wished to know and loved the great science of things an asked many questions and wished to be sent to the House of Scholars (A 23) but The State condemns him to be "a street sweeper", along with International 4-8818. Together they discover a dark tunnel where they secretly learn much more in those two years than all the ten years in the home of the student. They realize: We are false in the face of our brothers we are defying the will of the councils. We alone of the thousands are doing a work which has no purpose save that we wish to do it ... And yet we feel no shame, no regret, no burden in our spirit, no fear in our heart. Strange is the heart of evil. In our heart there is the first peace we have known in 20 years." (A 36)

"If this be vice, then we wish no virtue."(A 40) In their enthusiasm for work, knowledge and quest for the unknown, they discovered electricity. A discovery of such a nature by 'street sweepers' was a concept the world council of scholars could not digest. They considered the candle a

great boon to mankind approved by all men; therefore it cannot be destroyed by the whim of one.

How dared you think that your mind had greater wisdom than the minds of your brothers? How dared you gutter cleaner to hold yourself as one alone and with the thoughts of one and not of the many...? What is not done collectively cannot be good. (A 82)

The State council considers it a sin to give names which distinguish them from other men. But Equality $7-$ 2521 names Liberty 5-3000, 'The Golden One", and takes no heed of the law which says that men may not think of other men, save at the time of mating, when the council of Eugenics assigns (each spring) one woman of over eighteen to a man of over twenty. Children are permitted to be born each winter, when parents never see their children and children never know their parents. "Equality 7-2521 went twice to The Palace of Mating, but found it is an ugly and shameful matter". (A 42) when Equality 7-2521, disgusted with this social system, flees into the Unchartered Forest, The Golden One follows him. The Golden one looks upon Equality 7-2521 as a God Your eyes are a flame, but our brothers have neither hope nor fire. Your mouth is cut of granite, but our brothers are soft and humble. Your head is high, but our brothers cringe. You walk, but our brothers' crawl. We wish to be damned with you than blessed with all our brothers. (A 94) Many words are lost in the unmentionable times, especially one word which is not in the language of men, but which has been. And this is the unspeakable word which no man can speak nor bear. There is no crime punished by death In this world save this one crime of speaking the unspeakable word. And slowly, haltingly, like the words of a child the 'we' becomes the 'I'. (A 113) Rand champions the cause of the "I" here. "I am. I think. I will" (A 108) Of all the words granted to man, false and wise, only three words are considered holy: "I will It". My happiness is not the means to any end, neither am I the means to any end others may wish to accomplish. I am not a tool for their use. I am not a bandage for their wounds. I am a man. The miracle of me is mine to own kneel before. And we shall join hands when we wish and walk alone when we so desire. For in the temple of his spirit each man is alone. Let each man keep his temple untouched and undefiled. Then let him join hands with others if he wishes, but beyond his holy threshold. (A 115) Rand believes that the word 'We' must never be spoken save by one's choice, nor should it be placed first within man's soul else, it becomes a monster, the root of all the evils on earth, the root of man's torture by men, and unspeakable lie. Rand condemns the word 'We' because it crushes all beneath it, "and that which is 'white' and that which is 'black' is lost in the 'grey' of it ". (A 125) it is the word by which the depraved steal the virtue of the good, by which the weak, steal the might of the strong, by which the fools steal the wisdom of the sages. (Ibidem) This creed of corruption, this monster 'We', the word of serfdom, of plunder, of misery, falsehood and shame is over and the face of this God- this one word: '; I' by this word, man is taught the reverence of his own spiritthe spirit of Freedom. 
In both We the living and Anthem, Rand condemns the State's right interfere with individual rights. Hand portrays in this first phase how the individual's right is evaded, distorted, perverted, and seldom discussed. Rand believes 'right' to be 'a moral precept' as she observes in her article “Man's Rights."(Rand VOS 1964:96) Hegel in his book Phenomenology of the Mind argues that:

Rights provide a logical transition from the principle guiding an individual's action to the principles guiding his relationship with others. Individual right are the means of subordinating society to moral law. ${ }^{15}$ (Hegel 1967:121)

Rand ;attempts ot restore the dignity of the individual through both her protagonists, Kira Arugounova and Equality 7-2521 in We The Living and Anthem. In We The Living even though the protagonist is shot while crossing the Latvian border to freedom and to Leo, the overall emotional tone of the book is not tragic, but life - affirming. The State has the power to end Kira's life; it does not have the power to destroy her spiritually: she remains as he had begun, loyal to her knowledge of what life could be and should be. In Anthem, the protagonist Equality 7-2521 escapes with Liberty 5-3000, to rediscover themselves and their identity. Joseph Sobran, in his article; "Mussolini Shrugged: Ayn Rand Revived", says that "Rand's characters (in this phase) seem to speak on Rand's behalf and not for themselves". ${ }^{14}$ (Sobran 1989:53) In writing We the Living Rand knew that the major protagonist is not yet Rand's 'ideal man', rather Rand is concerned to demonstrate (here) a woman's feelings for her ideal man. The ideal man is born only in the world of The Fountainhead which will be dealt with in the next phase.

Through these novels, We The Living and Anthem Rand introduces the main concept of her Objectivist philosophy; Individualism versus collectivism. Rand observes in The Virtue of Selfishness that her aim is to condemn the altruist-collectivist premises "that the misfortune of some is a mortgage on others." (VOS 81) Rand offers her philosophy in its foetus form in this phase. It is a challenge to the modern conscience, and is Rand's clarion call to all those who are concerned about preserving one's right to individual freedom. Rand shows in "The Objectivist Ethics" that:

It is only to the frozen unreality inside a collectivized brain that human lives are interchangeable, and only such a brain can contemplate as "moral" or "desirable", the sacrifice of generations of living men, public benefits will bring to the unborn. (VOS 27)

Soviet Russia is the nearest, but not only illustration of the achievement of collectivized mentalities. Two generations of Russians have lived and toiled and died in misery waiting for the abundance promised by their rulers, who pleaded for patience while building public hope in five year installments. The waiting has no end. The unborn profiteers of that wholesale sacrificial slaughter will merely breed new hordes of sacrificial animals, as the history of all tyrannies has demonstrated while the unfocussed eyes of a collectivized brain will stare on, undeterred and speak of a vision of great service to mankind, mixing interchangeably the corpses of the present with the ghosts of the future, but seeing no men. Progress can come only out of men's surplus, that is, from the work of those men whose ability produces more than their personal consumption requires, those who are intellectually and financially able to venture out in pursuit of the new. Rand conceives of the present age a rapid epistemological degeneration, when men are being brought down to the level of concrete bound animals who are incapable of perceiving abstractions and this "makes it necessary for me to give the following warning to my readers: "Do not be misled by those who tell you that We The Living is outdated or no longer relevant to the present, since it deals with Soviet Russia in the 1920's".

We The Living is not a story about Soviet Russia in 1925. It is a story about dictatorship, any dictatorship, anywhere, at any time, whether it be soviet Russia, Nazi Germany, or (which this novel might do its share in helping to prevent a Socialist America. What the rule of brute force does to men and how it destroys the best will be the same in 1925, in 1955- whether the secret police is called G.P.U or N.K.V.D., whether men eat millet or bread, whether they live in novels or in housing projects, whether the rulers were red shirts or brown ones. (WTL 9)

We The Living and Anthem do not satisfy Rand stylistically. Certain aspects of it are a deep and lasting pride to her. Mimi Gladstein in The Ayn Rand Companion: An Analysis of her Fiction observes: "What Rand liked most was the plot structure; it was a singletracked series of events leading to a dramatic climax, a highly personal novel set against a social background. 15 (Gladstein 1982:57)

But there are other issues that presented the greatest difficulties. Rand is writing a new language. Sometimes she thinks in English, sometimes in Russian, at times even in French. American idioms come to her automatically, but Rand says, she is not fully satisfied with her way of saying things, with her narrative linguistic aspects. For example, many of the early passages pertaining to Kira's reactions to Leo are not quite right, they are too brief, too understated, particularly in emotional scenes, she feels that there is so much she wants to project, that she does not know how to capture it all, she is not yet at home in writing in essentials about emotions and moods, one has to do that by practice, one can't do it theoretically. (Ibidem: 61)

In We The Living the influence of Victor Hugo is seen on Rand. Quoting Rand, Gladstein observes that his influence shows itself in certain kind of over assertive, and slightly over dramatic turn of sentences:

My mind worked in those forms. I could not have any of my own yet, not on a first novel. The events leading to Andrei's suicide and the suicide itself were among the very few places where I was able to achieve deliberate under statement and indirection and implication. ${ }^{\mathbf{1 6}}$ (Ibidem)

It is only in The Fountainhead that Rand starts writing in her own style, and fully succeeds in the art of implication that is, building a strong emotional situation, then not naming it for the reader but writing around it. That makes the emotional impact stronger, according to Rand. 


\section{The Emergence of The Autonomous Individual}

The section that follows analyses the rise of individualism in Chinua Achebe's Things Fall Apart and Arrow of God respectively.

The world of Things Fall Apart and Arrow of God is a composite and compact world where characteristic Ibo rituals and practices are interspersed with the structural requisites of the major themes explored in them. Though these two novels do not follow each other, both deal with the pre-colonial, and early colonial days in the eastern part of Nigeria, occupied by Ibos. Historically Things Fall Apart and Arrow of God portray a phase of transition. The Nigerian people are faced with aliens in their midst. Christian missionaries establish themselves in this region by the nineteenth century only. So religion precedes politics in this particular entry into the 'exotic existence of Ibos. But the entry is extended beyond politics into all aspects of socio-cultural life.

Things Fall Apart portrays a vivid picture of Ibo society. It is remarkable for the recapturing of the buoyancy and vigour of traditional life. Order and significance exist. The plot revolves around the protagonist Okonkwo. It is as much the story of the whole clan as a single individual. The voice of Achebe, a wise sympathetic one is very much part of the tribe, his Ibo society, unlike Rand. But even in Achebe's novels, a transition from the 'communal' to the 'individual' is seen and implies a tension, but Achebe's achievement is not just the balancing of the two, more important is that the presentation of the social glide is from a narrative point of view, that is firmly from 'within' the tribe. There is no distinction between the sacred and the secular. Okonkwo symbolizes the values of pride and glory of his tribe. The divine directives are manifested in three powerful forces: The Oracle of the Hills and Caves, the Chi and Mother Earth, the Goddess. The protagonists is each of the books come into direct contact with the supernatural powers dwelling in their midst, and feel what is means to submit to them. For instance, the Oracle of the Hills and Caves is deeply involved in the tragic fate of Ikemefuna: "Yes, Umofia has decided to kill him. The Oracle has pronounced it."(TFA5) The death of Ikemefuna could be viewed as calculated murder especially a son by a father, because there is a shift in values in the whole community. The involvement and relieves it of the guilt associated with bloodshed and wins the approbation of "communal consciousness.'(TFA 9) But Achebe places the event in an individual perspective too, raising the incident to the fore and suggesting a very subtle alternative. It echoes the beginnings of a new individualistic humanism. The response of the individual consciousness is seen through Obierika and Nwoye. Max Weber says in Sociology of Religion that the 'savagery' associated with primitivism' ${ }^{17}$ (Weber 1971:45) makes itself manifest in the most ruthless manner in the case of Ikemefuna. Ezendu informs Okonkwo that Umuofia has decided to kill the boy calls you his father. Here Ezendu proposes human predicament neither to defy the gods by resisting, nor offend one's conscience by assisting in the death. Okonkwo's vision is blinded because of his fear to be thought weak to fulfill his desire to the Oracle and his idea of masculinity. Wisdom and maturity seem to be the touchstone of the tribe. Okonkwo tries to win the tribe's praise but ironically loses it and that is Okonkwo's personal

tragedy too. Okonkwo is likened to one who dares to wrestle with his spirit, for even as a man of eighteen, he had earned popularity by throwing, an unbeaten wrestler "in a fight which the old men agreed was one of the fiercest since the founder of their own town engaged a spirit of the wild for seven days and seven nights". (TFA 1) Later, in the sacred Week of Peace, he beats one of his wives thus showing that he had no respects for the gods of his clan. His enemies said that his good fortune had made him proud and likened him to the little bird Aza who so forgot himself after a heavy meal that he challenged his chi". (TFA 26)

Using proverbs Achebe reinforces the image of Okonkwo as a man who struggles with his Chi, when everyone at the kindred meeting took sides with Osazo. When Okonkwo called him a woman, the oldest man present tells Okonkwo "that those whose palm-kernels' were cracked for them by benevolent spirit should not forget to be humble". (TFA 39) Okonkwo apologizes.

But it was really not true that Okonkwo's palm-kernels' had been cracked for him by a benevolent spirit. He had cracked them himself... At an early age he had achieved fame as the greatest wrestler in all the land. That was not luck. At the most one could say that his Chi or personal god was good. But the Ibo people have a proverb that when a man says "yes", his Chi agreed. And not only his Chi but his clan too, because it judged a man by the work of his hand. (TFA 2223)

In his exile he had come close to understanding that his personal god or Chi was not made for great things. A man could not rise beyond the destiny of his Chi. The saying of the elders was not true-that if a man said 'yes' his Chi also affirmed. He was a man whose Chi said 'no' despite his own affirmation. (TFA 117)

However, he returns with the false hope that his Chi and his clan would now be making amends for the past disaster.

He is unable to resume his former position of leadership for the village has changed. So, even though he says "yes" very strongly, his chi and his clan say "no." Okonkwo's tragedy is that he is unwilling to adapt himself to the changing times. He tries to recreate the old way of life which is gradually disappearing. He makes rash steps to resist the forces of colonial change, stumbles and falls. Okonkwo's fall is symbolically the fall of the traditional Ibo society. For his hero, Achebe

...wanted a character that could be called representative of this particular group of people... who may admire a man of strength ... The weakness of this particular society is a lack of adaption, but being able to sense... I think in (Okonkwo) time, the strong men were those who did not fend and I think this was a fault in the culture itself. (TFA 120)

Achebe's sympathies are not entirely with Okonkwo for he believes as he observes in "Cultural Events in Africa", that "Life has to go on and if you refuse to accept changes, then tragic though it may be, you are swept aside". ${ }^{18}$ (Achebe 1967:11) Achebe's portrayal of Ibo society is compassionate. He shows how this noble, simple, poetic way of life gets frozen. 
Yet he does not hide its occasional inhuman practices like ritual murder, killing of twins and its emphasis in manliness which brings down both the hero and the society.

Obierika admits that tribal ethics, for all its flexibility does not provide an easy answer when it comes to choosing between personal claims and social commitments. The Ikemefuna incident highlights both the overpowering 'traditionalism' and the streaks of 'individualism' that would seem to be on the rise, and results in the unique form of individualism pioneered and championed by Nwoye.

As soon as his father walked in that night, Nwoye knew that Ikemefuna had been killed, and something seemed to give way inside him, like the snapping of a tightened bow. He did not cry. He just hung limp. (TFA 59-60)

The concept of individualism and its relations to the coming of Christianity brought about subsequent changes in Ibo life. The individual is invariably in conflict with the force that is society or tradition preserved with religious sentiments. Emmanuel Obiechina, in his scholarly enquiry into the Culture, Tradition and Society in the West African Novel maintains that: "the identification of the individual with the group of which he forms a part, and its social and cultural outlook, is the very essence of traditionalism". ${ }^{19}$ (Obiechina 1975:202) besides acquiescing the beliefs and customs of the group. This is the value often emphasized by most novelists, who contrast it with the opposite value based in self interest that marks a more "developed" situation. But along with social conformity and the discouragement of deviation from the common norms, traditionalism involved a certain amount of the repressive curbing of individual freedom. Erich From in The Sane Society uses the word 'submission' to denote the various ways in which an individual relates himself to the rest of the society. ${ }^{20}$ (Fromm 1956-30).

He maintains that the individual in this way "transcends the separateness of his individual existence by becoming part of somebody or something, bigger than himself and experiences his identity in connection with the power to which he has submitted". ${ }^{21}$ (Ibidem: 38) It leads us to assume that any movement contrary to this coordinating gesture any attempt at the severance of the total integrity of the can is taboo and anathema to a tribal society. Irrespective of the means employed, the individual is bound to the milieu inseparably. He can achieve this coordination by integrating himself willfully and consciously to its entire body, by transcending the individualistic traits in him, or by pure 'submission'.

Things Fall Apart is a record of a steady transformation of the individual from his integrated existence to independent existence. It is a long process. The contradictions, tribal commands and its values, lead to its own downfall in Umuofia. The inscrutability and arbitrariness of the religious dictates puzzle Obierika and Nwoye equally. The technique Achebe employs is juxtaposing the tribal and the personal very effectively, bringing out the paradoxes that sustain a social superstructure. Obierika thinks for us when he asks "why should a man suffer grievously for an offence he had committed inadvertently?' (TFA 113) The anguish is terrible for the new individual thinking. Achebe does not probe deeper into the nature of the inner adjustment of the

individual being torn between loyalties from within the structure of the tribal society itself. Focused from that point of view, the incompatibility of human and divine values and their paradoxical and inextricable involvement creates a stasis, a stagnant equilibrium, which admits of no synthesis and suggests no possible dialectic.

Achebe's treatment of Christianity is so detached that it has not been possible to decipher his attitude towards Christianity. There is no sudden conversion or dramatic confrontations. This new religion enters quietly and touches vulnerable points of their culture. There is no urgency and no fear of the tribals. The early converts were "excrement of the clan, the new faith a mad dog that had come to eat it up", (TFA 13) Okonkwo's son, Nwoye is converted much to Okonkwo's displeasure. For Nwoye, a new "frame of orientation,"22 (Obiechina 1975:222) much more flexible and appealing to the human emotion is tangible in Christianity. Obiechina observes that in the new religion the whole tribe mattered, not individuals:

It is not the mad logic of the trinity that had captivated Nwoye. He did not understand it. It was the poetry of the new religion, something felt in the marrow. The hymn about brothers who sat in darkness and in fear seemed to answer a vague and persistent question that haunted his young soul - the question of the twins crying in the bush and the question of Ikemefuna who was killed. He felt a relief within as the hymn poured into his parched soul. The words of the hymn were like the drops of frozen rain melting on the dry palate of the panting earth. (TFA 137)

Nwoye's instantaneous response is not expected but very consistent with the logic of his consciousness. It appeals to a deed neatly and deeply felt, but not neatly formulated.

The point is not whether the Christian God equals in power to the great Chukwu but the loving personal care appeals to the whole unresolved fear-syndrome, so rampant in Umuofia.

The progress of Christianity meant the reassimilation of all that was considered undesirable by the tribe-the Osu, the slave, the twins the effeminate, into a confraternity of love: For them:"The new religious profession of basic human quality, the universal fatherhood of God and the universal brotherhood of man constitutes an awakening of submerged hopes, a resurrection of a sense of human worth, long buried under the grave mound of custom."23 (Obiechina 1975: 224) The appeal is largely on the emotional and psychological level. Nwoye sees it as a liberating force. David Carroll says in Chinua Achebe that for Obi, this new religious awareness implies acceptance for the outcasts of the tribe. ${ }^{24}$ (Carroll 1980:56). Critics view the alien religion as disrupting Africa's culture. The novel features it that way, but the Christian religion does have its contributions to African culture. Economically education widens the outlook of life. But it also has undermined the solidarity of the tribe. With Mr. Smith on the scene, there were no negotiative attempts between rival myths and the slaying of the Gods of Baal. Sacred practices of the tribe like the unmasking in public 'an egwugwu' was defied. ${ }^{25}$ (Ibidem :56). 


\section{The Emergence of The Autonomous Individual}

The tribal narrative voice, so far authoritative seems to be less confident and shakier. (TFA 168-169)

That night the mother of the spirits walked. ... weeping for her murdered son. It has a terrible night. Not even the oldest man in Umuofia had ever heard such a strange and fearful sound, and it was never to be heard again. It seemed as if the very soul of the tribe wept for a great evil that was coming - its own death. (TFA 171-172)

The tribe here mourns its own demise, a unique act of rebellion, an expiation of a crime, where even the narrative voice falters, never to be heard again. Umuofia yields \& disintegrates. Along with the tribe sinks its own value system, religious as well as socio-economic. A new administrative setup and a fresh economic growth, give rise to individualism. Assessment of wealth has its dual aspects - the extinction of a compact system that believes its corporal ownership and the development of individual ownership. It means advanced thinking on the economic lines: "Mr. Brown triggered off a new trend in the thinking patterns in schools and managed to win the affection of the clan", (TFA 160) because he treads softly on its faith. He realizes a frontal attack will not succeed. Even the narrative voice seems to appreciate the manner in which Mr. Brown approaches the tribe, its religion and leaders, though it is in his interest. Schools and religion go hand in hand from the beginning. (TFA 164) Young Nwoye, now called Isaac, undergoes training as a teacher.

The change that Umuofia visualizes, the growth of formal educational facilities, personal approach to religion and a new economic thinking is so instantaneous and effective, that Okonkwo, on his return from exile, finds himself amidst a different social order, "one based on individual contractual relationship as opposed to the traditional and collective kinships hitherto existed". ${ }^{26}$ (Weber 1930: 59-76).The white men have taken over the administration of the tribe. Obeirka says that his own men are against the tribe. "He has put a knife on the things that held us together and we have fallen apart". (TFA 158).

Thus an eventual release from conventional social ties gives the individual an impetus and motivation to reshape his whole pattern of life rather than maintain the status quo. Nwoye severed from his family, but accepted and established in the new dispensation, holds forth the image of this new individual. There is a change from the 'communal', to the 'individual'. This brings about a conflict but Achebe manages to balance the two. There is also a social glide from the point of view of the narrator from within the tribe. Neil McEwen in Africa and the Novel observes two distinct narratives voices: 'traditionalcommunal', and the modern individual. ${ }^{27}$ (McEwen 1983:22-25) In the first two thirds of the novel, the 'communal' voice is heard through a mixture of anecdotes and gossip, folk-tales and proverbs, in which the emphasis is on experience that is shared rather than as it appears to any individual consciousness. In the last part of the novel is heard the voice of the 'modern individual' - the urban editorial voice, who sees beyond the view point of the villagers, who are now 'they' rather than 'we' and who presents the decay of traditionalism. The colonial mentality and the coming of Christianity form a large, more balanced and detached perspective, in a more distanced and elaborate style:

They were many men and women in Umuofia who did not feel as strongly as Okonkwo about the new dispensation. The white men had indeed brought a lunatic religion, but he had also built a trading store and for the first time palm-oil and kernel became things of great price and much money flowed into Umuofia. (TFA 126)

The narrative of Things Fall Apart modulates, through this interchange of narrative voices, from the communal voice of the village to the voice of the individual consciousness and back again, so that the two interpenetrate.

Arrow of God, a fitting sequel to Things Fall Apart takes us one step further away from the sociopolitical situation portrayed in the latter, where the narrative ends as the tribe realizes that it comes to terms with the alien force which is powerful and irreversible. Arrow of God is a richer, more dynamic and complex world with an elegance that comes of its multi-dimensional capturing of the Ibo society in 1921. It explores simultaneously the depth of three elements evolved in the artistic apprehension of a particular historical movement. The tribal world of Umuaro created around its chief Priest Ezeulu, the colonial administrator's world and its political concerns, symbolized by Colonial Winter bottom, the Missionary world represented by Catechists John good country and Moses Unachuku. These three have independent existence put together they form a totality, vast and mature, with revealing portraits of personal and social modes. Achebe is at his best in Arrow of God, which is a rich and renewed representation of traditional Ibo ethos within which Ezeulu tries to assert his individuality.

The role of the white men here as agents of change is different from Things Fall Apart. In an article title, "The Human Dimension of History in Arrow of God", Obiechina writes:

The local school and mission station, irreverent strangers like the catechist Good Country and the inarticulate though palpable reality of the Whiteman's administrative presence, all these have undermined traditional confidence and shakes the sense of common purpose and solidarity which in the past constitutes the spirit of traditionalism. ${ }^{28}$ (Obi china 1979:170)

The people of Umuaro have come to view these changes without bitterness. Ezeulu contains the contradictions relating to the privileged role he plays, when the priest as Max Weber terms 'specially called' or 'set apart' from the category called 'most men' has been perceived as somehow more in touch with the transcendental realities than other men, as a spiritual leader, a divine sportsman, an intermediary between men and deity, and even the bearer of the people's spiritual burdens, he ministers at all stages of man's rites of passage and his personality may at times be defined in terms of the attributes of the God whom he serves. ${ }^{29}$ (Weber 1930: 20-31) But he is only the servant of God. It is not his individual will, but the will of the deity that guides him along.

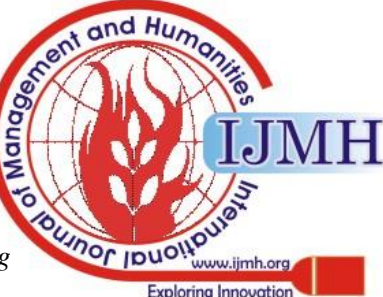


The tragedy of Ezeulu is that he tries to be 'himself', 'individualistic', identifying himself with the God whom he is expected to serve; defying the precept that "... no matter how strong or great a man he was he should never challenge his chi”. (AOG 27)

It is within this broad framework that Achebe establishes once again that and individual, priest or no priest, has real valid existence only in terms of the community. The norms of the society exact conformity from the individual, discouraging deviations and subversions of the common will and emphasize the primacy of the group over the individuals who compose it. This is reinforced in the fate of characters like Okonkwo and Ezeulu who are important and powerful in their own rights, yet as one sees, in their conflicts with their communities, the supremacy of the latter is soon established.

The Feast of the Pumpkin Leaves (AOG 66-73) is a dramatic realization of the major priestly function of Ezeulu. David Carroll says it is private as well as public drama: "The power of the scene comes from the effortless interaction of the individual \& community, which at the climax, merge in the ritual gesture"30 (Carroll 1980:90) On the one hand Achebe seeks to give unity and authentically to the festival through the drums, the dancing in union, the cloud of dust and the imagery. The ilo sounds like a vast swarm of giant flying insects. But this unified reality is repeatedly intruded upon and fragmented by the intervention of individual perspective artistically blended into it, like the fears and rivalries of Ezeulu's wives, the meeting of friends which are then gathered up into the totality of the larger ritual. This part is the most representative gesture of the fundamental vital rhythm of Ibo life (AOG 60)

The whole novel can be read as a search for individuality in the context of strong tribal affirmations, a quest for identity, characterized by personal idiosyncrasies. Ezeulu's misgiving as he tries to assess his powers, takes one right into the heart of the problem:

No. the chief priest of Ulu was more than that, must be more than that. If he should refuse to name the day there would be no festival-no planting and no reaping. (AOG 3) Achebe goes on to follow Ezeulu's consciousness in argument with itself: "what kind of power was it if it would never be used?" (AOG 4) Ezeulu the man cannot be separated from Ezeulu the Chief Priest. Because of this, some critics regard the novel as depicting the desperate attempts of an individualistic high priest to redefine his relation to the society. The paradox of his office is indicated in his ceremonial appearance. He is half man and half spirit. In the world of man he is very powerful, in the world of spirits he is a servant. The duality of his person and position is almost incomprehensible to the 'man' Ezeulu, which leads his to shifting loyalties from the 'Divine' to the 'Human'.

This discrepancy between 'Divine' and 'Human' becomes more acute and apparent in Arrow of God than in Things Fall Apart. Every minor event in the novel testifies to the theme that is explored and one's attention is immediately focused on Ezeulu whose character embodies this dilemma in its most acute form. In complexity too, Ezeulu, far outdoes the hero of Things Fall Apart. Okonkwo's pride and assertiveness springs from his literal loyalty to the tribe and values upheld by it. That Ezeulu is proud and arrogant in his own right, and his personal drives and ambition in constant conflict with the expectations of the tribe, is highlighted throughout. But as Okonkwo discovers:

A society based on a flexible balancing of competing claims is not the most comfortable place for a domineering personality. No one, not even a God is safe from criticism; there are always other people, other Gods, ready to supplant their predecessors in these shifting, of skeptic Ibo communities. (TFA: 92)

The main threat is that Ezeulu attempts to identify himself with Ulu and imposes his will as the gods come from Nwaka, the most titled man in the whole of the six villages. Nwaka's insight into the personality of Ezeulu maintains that "He is a man of ambition: he wants to be king, priest, divine, all. His father they said was like that. But the Umuaro people showed him that Ibo people knew no kings". (AOG 27-28) But as Ezeulu sees it, since the highest spiritual values are attached to his priestly tasks, any autonomous individual would tend to regard his achievements as a quasi-divine mastering of the whole situation and environments. Obvious that Ezeulu is quite conscious of his vulnerable position and this explains his closely scrutinizing the nature of his power in the beginning of the novel. He recalls how his authority was challenged five years ago over the war with Okperi. He advised Umuaro not to fight for a piece of land which was not theirs and warned them that Ulu would not support an unjust claim. But "Umuaro is today challenging its Chi ... some people are still talking of carrying war to Okperi. Do they think that Ulu will fight in blame?" (AOG 27) Nwaka, however, refuses to accept the priest's authority and exclaims that his powers should be exclusively limited to the rituals as "the man who carries a deity is not a king. He is there to perform his God's ritual and carry sacrifices to him." (AOG 27) The significance of 'Chi' is once again brought to the limelight, whereas Ezeulu thinks that it is an offence to challenge one's 'Chi'. Nwaka asserts that "if a man says, 'yes', his 'Chi' also says 'yes.' (AOG 28) Though Nwaka won the argument, Umuaro lost the battle, the disputed and being given to Okperi by the white men. But the question of Ezeulu's identity in terms of his deity is still in a crisis and shrouded in mystery. Now his position as the unifying symbol of the tribe appears shaky.

In a sense, the inadequacy in the tribal set up, the fact that it has no room at all for individuality, in some ways parallels the problems of Ikemefuna and the twins in Things Fall Apart. What it points to is the limits of an old humanism prevalent in the tribe and how a socio-political order uses it. In the long run it leads to strangers making steady inroads into the traditional communities and creating wide chasms out of mild cracks. What interests us is the thought process of certain individuals in such a transitional phase, revealing the conflicts involved in the mental adjustments demanded of them. It is indeed fascinating in West African fictional locus, that against the innumerable literary creations celebrating the purely communal ethics in

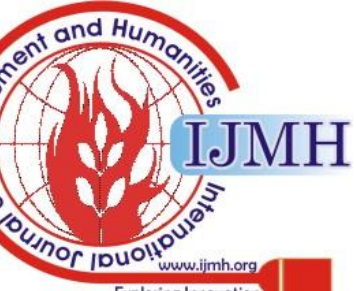




\section{The Emergence of The Autonomous Individual}

Arrow of God, Achebe has upheld the validity of an individualist mode of thinking. Hence there is no lamenting over things falling apart, but a very objective, realistic picture of Ibos at a phase where the encounter with the European values meant accommodation and assimilation rather than protest and conflict. Ezeulu is far more aware of the changing responds to it in an exceptionally more mature manner than the rest of his clansman. "The world is changing", he had told him (Oduche). "I do not like it. But I am like him". When he was asked why he was always on the wing he replied, "men of today have learnt to shoot without missing and so I have learnt to fly without perching." (AOG 45) This renders him capable of deeper perception into the nature of things and a greater adaptability to changing conditions: Ezeulu's experience is treated by Achebe as something that is of little validity to the tribal world, that of the inward moral being of the individual. Thus though Achebe does not release his hero from the determining ties of his society, the delineation of Ezeulu's character is marked by a radically individualistic approach. And in Arrow of God, self-examination, introspection and personal reflection lie interspersed with social documentation. The hero's consciousness is the Joycean Stream of Consciousness. His reflection over his image as the priest of Ulu, his decision to send Uduche to the white man's school, his leading role in the colorful celebration of the Feast of the Pumpkin Leaves, his witnessing against Umuaro in the land dispute with Okperi, his rejection of the 'warrant chieftaincy' and finally his refusal to proclaim the day for the New Yam Festivaleverything is elaborated and gathered into a crescendo of controlling perfection from which Ezeulu has no escape. What happens in the course is a steady progressive alienation from his surroundings, a denial of normal human relations. By the end of the novel, the alienation is complete and turns out ot be fatal, and his friend Akuebue tells him. "no man however great can win judgment against a clan”. (AOG 131)

The consciousness of the hero provides us with a glimpse into its depths will all its subtlety and complexity. He is not merely an appendage of the clan, but a world by himself, confined as it is, and conceived in 'Superhuman' proportions. The reader shares doubts and fears and ambitions of the High Priest wholly partaking of their eventual development into an obsession, until they reach a natural climax. Thus, the thematic progression is made logical and lucid rather than super-imposed. However, an element of Ezeulu pervades Ezeulu, befitting a Priest who dwells in a sanctorum, the sublimity that is part of the transcendental scheme of things. As Ezeulu himself says:

I have my own way and I shall follow it. I can see things where other men are blind. That is why, I am thrown and at the same time I am thrown able, you cannot know the thing which beats the drum to which Ezeulu dances. (AOG 132)

But these new internalized democratic, individualistic ethos evolves out of Ezeulu's own theistic apprehensions, and does not add to his priestly stature in the existing milieu. His final confrontation with the demand of the collective body of the tribe is prior to the New Yam Festival which he manipulates to assert his own rights. Ezeulu refuses to accept warrant chieftaincy, infuriates
Winter bottom the District commissioner and this results in his imprisonment for thirty two days. This unexpected event adds a new dimension to the jealousy among the tribes of Umuaro. In his return from prison, Ezeulu recounts and broods over hid grievances against Umaro. The fights between Ezeulu and Ezidemili, mainly represented by Nwaka, are always seen as a threat to the power and authority of the chief priests of Ulu. Vengeance fumes in his mind, yet he is overwhelmed by the warmth of the welcome he receives from the whole of Umuaro on his return from captivity. Oscillating between the two options of revenge and reconciliation with his community, he begins "to probe with the sensitiveness of a snail's horn, the possibilities of reconciliation, or if that was too much, then narrowing down the area of conflict". (AOG 191) His imaginative recreation of tribal harmony attempts a striking balance between his human and divine roles; Ezeulu in fact does not feel any more the need to affirm that his power over the tribe is absolute.

This new found sense of the community is described by the one direct intervention of Ulu in the novel, where his voice falls on Ezeulu like a thunderbolt:

Ta: Nwanu: barked Ulu in his ear, as a spirit would in the ear of an impertinent human child. "Who told you that this was your own fight?" Ezeulu trembled and said nothing, his gaze lowered to the floor. "You want to save your friends who bought you palm wine: Beware you do not come between me and my victim or you may receive blows not meant for you: Do you not know what happens when elephants fight? Go home and sleep and leave me settle my quarrel with Idemili whose envy seeks to destroy me, That his python may again come to power.

As for me and Idemili, we shall fight to the finish; and whoever throws the other down will strip him off his ankle. (AOG 191-192)

Ulu reasserts his control over the divine-half of Ezeulu's ambiguous nature in an unmistakable way, and all doubts and perplexities are resolved. The assertive priest's ambition and eagerness to identify with his God, and act on his behalf only provokes his wrath. The priest is nothing more than the remote agent of Ulu: After that there was no more to be said. Who was Ezeulu to tell his deity how to fight the jealous cult of the sacred python? It was a fight of the Gods. He was no more than an arrow in the bow of his gods. This thought intoxicated Ezeulu like palm-wine. New thoughts tumbled over themselves and past events took on new exciting significance. Why had Oduche imprisoned a python in his box? It had been blamed on the white man's religion; but was that the true cause? What if the boy was also an arrow in the hand of Ulu? (AOG 192) Ezeulu's madness takes the form of an extreme individualism, which means an assertion of complete independence from the reality of his existence. The next part of the novel, till the end, depicts the struggle embodied in the person of Ezeulu. Presumptuous as he might be called, he lets himself to be ruled by the 'Secular' half in him rather than the 'sacred', and decides to hit Umuaro at its most vulnerable point-the Feast of the New Yam. 
He is a conformist with a vengeance; and considers himself 'sinned against rather than sinning'. The Feast takes on a new significance. Everything is made subordinate to the conflict with the rival God. Ezeulu should exact punishment from Umuaro for dividing its loyalty to him with the sacred python of Idemili. Achebe follows at length the 'subjective' in Ezeulu where he tries to rationalize his 'ungodly' approach and seeks peace with himself. Thus he keeps up the enduring image of Ezeulu in his single-minded pursuit of a solid individuality.

The image of the implacable Ezeulu is highlighted. He refuses to proclaim the Feast of the New Yam. He is determined to manifest that he is not just an 'Arrow of God', rather, somebody more potent and powerful. "I only call a new festival when there is one Yam left from the last. Today I have three yams and so I know that the time has not come. (AOG 27) He means to make them wait the next two moons to eat the remaining sacred yams. "Ulu did say that two new moons came and went there was no one to break kola nut to him and Umuaro kept silent". (AOG 208) The yam harvests rot in the field and Ezeulu remains unappeased, the question of his power over the clan occupies our concern once again. Is it absolute or confidential? The question on the opening pages of the novel takes on a new relevance and depth here: "If he should refuse to name the day... But could he refuse? No (AOG 3) He has refused and now tries to establish that it was done on the authority conferred on him by his God, extending a purely human act of personal revenge to a transcendental dimension.

With the same skill seen in Things Fall Apart, Achebe insinuates the growing challenge faced by Umuaro by the growth of Christianity, which seizes this moment of discord very effectively. One begins to hear the sound of the mission by the very heart of Umuaro; near the sacred shrine of Ulu.The narratives gain a powerful effect by the juxtaposition of two polarities embodied in two different religions:

As Ezeulu cast his string of cowries, the bell of Oduche's people began to ring. For one brief moment he was distracted by its sad, measured monotone and he thought how strange it was that it should sound so near - much nearer than it did in his compound. (AOG 210)

In a point of deadlock and despair the missionaries intervene and announce their own harvest festival, "whoever made his thanks offering to God, they could harvest their crops without fear of Ulu" (AOG 215) Desperate and confused the people turn to the Christian religion for help. They send their sons with yam offerings to the Church and harvest their Ezeulu's famous son serves as the end of the human drama. It disturbs Ezeulu's mind and sparks off the madness in Ezeulu's family and finally resolves the tension built up between Ulu, his priest, and clan. Ezeulu, broken, does not understand Ulu's desire to strike him down and cover him with mud. It shook Umuaro to the roots; they felt that "a man like him, did not come into the world too often". (AOG 229) The final act of the insane proves to be a blessing in disguise. "It allowed Ezeulu, in his last days to Chief Priest could ever refuse. So it could not be done". crops in the name of new God. The sudden death Obika,

live in the haughty splendour of a demented high priest and spared him knowledge of the final outcome". (AOG 229)

A scrutiny of the text reveals a certain strain placed on the plot in the novelist's attempt to interrelate the three worlds into a coherent whole and almost all the characters are conspicuous for their inability to handle their situations and an immature grasp of events. The author is unwilling to commit himself with any precision as to the nature of the interior and exterior realities of the tribal religious world. One accepts the element of the inexplicable and the mysterious, as part of the world. Achebe tries to convince us that the ways of Ulu are untraceable and beyond the reach of man. However, for Umuaro it is simple.

Their Gods had taken sides with them against his headstrong and ambitious priest and thus upheld the wisdom of their ancestors - that no man however great was greater than his people; that no one ever won judgment against his clan. (AOG 230)

The last word belongs to the novelist who sees the whole narrative in its total historical context. He argues that of Ulu had meant to teach his priest loyalty and tribal wisdom, he had chosen a dangerous time for this, for "a deity who chose a time such as this to destroy a priest or abandon him to his enemies was inciting people to take liberties, and Umuaro was just ripe to do so". (AOG 230)

The mass defection of the tribe to Christianity must be seen as the result of the failure of the old dispensation to provide security to the people.

As in Things Fall Apart the inadequacies of a disintegrating system provides space and accommodation for more flexibility of values, which acquires a stronger foothold in a time of crises.

With this historical dilemma, Achebe exposes the human realities faced by men and women who are caught up in it. The human dimension of it is concentrated on the high priest, the most fully individual character in the novel, who at the end of the novel stands free of all rituals and abstractions. He is defeated because his grasp of the situation is inadequate. Yet the changed valued and attitudes reflected in Arrow of God prepare us for a more radical departure from the tribal modes in thinking as well as in lived realities. Thus both Ayn Rand and Chinua Achebe can be considered as social realists in this phase, as both the authors highlight realistically the different situations in their respective societies. While Rand portrays the realism as existed in the Communist Russian Society and shows the individual's struggle to emerge from such a claustrophobic system in her fiction We the Living and Anthem, Chinua Achebe portrays the realism that existed in the traditional Ibo Society and depicts the transition from a communal to an independent, individual existence, in his fiction, Things Fall Apart and Arrow of God.

Rand's power lies in her depiction of the grim terror that prevailed even in the supposed golden age of Lenin. Everyone is reduced to a debasing dependence on the state, not because of the fear of arbitrary arrest but because of the total absence of property rights and economic freedom.

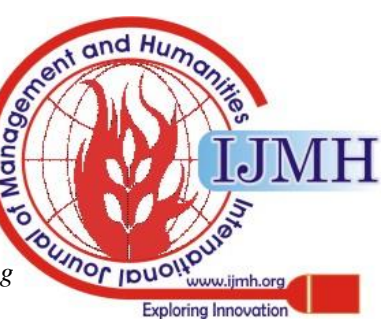




\section{The Emergence of The Autonomous Individual}

One can be suddenly deprived of anything, job, possessions, living quarter, that is coveted by some Party hack. The characters are driven to corruption, prostitution, and treachery by the system that promised them 'liberation'. We The Living and Anthem, make the issue of property rights vivid and vital. It also shows the formation of a malign status system in a society where connections are everything and talent is next to nothing.

Achebe, in Things Fall Apart and Arrow of God, reveal the depth and inclusiveness of the pre-colonial Ibo society, and shows a clan of people who live a rich and rhythmic way of life that gradually becomes frozen. Through the stories of Okonkwo and Ezeulu, Achebe pays a tribute to the dignity of the Ibo tribe and their ancestors. But while Achebe recaptures the vigour of traditional life, where the life of individual, the beliefs, rituals and ceremonies of the community are merged into an order and significance, presenting a centre that will hold, Rand shows how her individuals are unable to cope with the Communist system. Even at the cost of their lives, they preserve their own 'sense of life' till the end. Though Kira is killed, Andrei shoots himself, and Leo chooses to live as a prosperous gigolo, the protagonists could be considered successful, unlike Achebe's protagonists who meet with defeat. Okonkwo, is like Kira in one sense, they never change. They are in the end as they were in the beginning. They never give up their 'sense of life' though life and society deal hardly with them.

Both societies throw light on a different kind of a collective system. Rand depicts an opportunistic, parasitical communist society; Achebe depicts a peaceful, well-knit communal Ibo society. Rand and Achebe's objectives in writing the fiction belonging to Phase I evolve from their different convictions. While Rand wrote We the Living and Anthem to warn America of her Russian nightmare, Achebe in Things Fall Apart and Arrow of God laments the loss of a rich and glorious past.

Thematically, Rand explores the sanctity of individual human life in this phase while Achebe depicts the crisis of the Collective Soul. Both Rand and Achebe hold up a gripping plot and a property almost unique, which portrays the individual's struggle against a society which attempts to overpower them. Here in this first phase, Rand's protagonist's lives end drastically. This is because Rand's protagonists live up to their own 'sense of life' and do not give up their struggle to maintain their own individual status quo, unlike Achebe's protagonists, who succumb to the social norms of their society and are unable to flout completely the restraint of the Ibo society on them. So while Kira of We the Living succeeds to reach the Latvian border, beyond which her 'top value' Leo Kovalevsky has escaped, she is shot in the process of the struggle. The individual is destroyed physically but not mentally or spiritually proving that "life undefeated existed and could exist". (WTL 446) Okonkwo of Things Fall Apart is unable to accept the flexibility of his society and commits suicide. There is a conversion that takes place in the heart of Ayn Rand's most remarkable character Andrei Taganov, 'the reddest communist ever' (WTL 24) and in Chinua Achebe's Character, Nwoye. Both Andrei and Nwoye are gradually convinced of the absurdity and the inhumanity of the Communist party and the tribal ethos respectively.
While Andrei loses all faith and hope in his G.P.U. becoming almost an individual in the end, Nwoye loses all faith and hope in his tribal society; and finding the logic and humanity of the Christian religion more meaningful, joins the Christian Church as Isaac. Ezeulu of Arrow of God is also unable to relate his own selfish desires with those of his society's demands and becomes mad in the end.

In this first phase, the individuals hold out little hope, except in Anthem where the worthwhile protagonists exhibit abilities that are 'society shaking'. (A 6) Equality 72521 is a creator and inventor in the tradition of Galileo, Edison and Einstein. In a world where all technological advancement has been lost, he discovers electricity and is able to move beyond the shackles of his limited education. He not only invents but defies. When his society is unable to accept what he offers, he escapes through uncharted forests to form a new colony of his own, where he and the others who wish to throw off the chains of collectivism can develop individually.

What is highly remarkable in this first phase is that the seeds of 'individualism' in the fiction of both Rand and Achebe are deeply planted. All the protagonists in the four books chosen to represent this early phase are seen striving to assert their own individuality. In the overall perspective of Rand's philosophy. The State evolves a loser and the individuals are the winners. The individuals begin their evolution and is seen growing in the next phase into the 'man-child' of The Fountainhead; believing that the Ego is the fountainhead of all human progress and society is nothing but an empty shell. In the next phase, the Randian concept of society further deteriorates, when society is no more "The State" or any dictatorial system as in Phase I, but the evil men-'second handers', 'social suckers'or 'parasites'.

With Achebe, the individuals are seen emerging from a well-knit, harmonious, ordered and disciplined society, unlike the corrupt and inhuman society of Rand. In this phase, Ibo society is at its best, but with the intervention of the Whiteman, things fall apart and the centre can no more hold them together. Gradually as the seeds of individualism sprout here, the clan no longer can think or feel as one, and succumbs to the influences of an alien force. The socio-cultural richness of the Ibo society if seen deteriorating gradually in the next two phases and the Ibo's are no longer at ease as they were. The individuals are portrayed as heroic, chivalrous and courageous men of deep thought and action, but as they emerge as individuals, they grow more corrupt and cowardly and also deteriorate. Okonkwo is cast in a better mould than Ezeulu; and Obi Okonkwo and Odili Samulu are still lesser men than Okonkwo and Ezeulu. In Rand's fiction, society deteriorates but the individual changes and develops in a linear progression. In Achebe's society the individuals change for the worse, though Achebe believes that change is a must. Ayn Rand, being an emancipated woman writer, casts three of her, five protagonists as women; but Achebe, hailing from a chauvinistic, male-dominated society casts all his protagonists as men, except for Beatrice in Anthills of the Savannah.

Published By: 
In this early phase, Rand introduces her first woman protagonist. Kira Arugounova, and Liberty 5-3000 in Anthem, follows the male protagonist, Equality 7-2521 to the Uncharted Forest. In phase I, Achebe depicts only male protagonists, namely Okonkwo and Ezeulu. Women characters have no significant part to play except for Ezinma in Things Fall Apart, and are merely objects performing a junction.

In We the Living and Anthem Rand has not yet fully developed her concept of the ideal man, nor her concept of the parasitical society. The protagonists here, as the protagonists of Achebe are not portrayed as productive, since they do not contribute materially, as they do in the next phase. Kira Argounova, Leo Kovalensky, Andrei Taganov of We The Living, Equality 7-2521 and liberty 53000 of Anthem, and Okonkwo and Ezeulu of Things Fall Apart and Arrow of God respectively, are all 'chief strivers' and heroic individuals. But the two characters of actual achievement are Andrei Taganov of We the Living and Okonkwo of Things Fall Apart. Andrei is a hero whose bravery has been demonstrated in the battle of Melitopol. He risks his life to convince the White Army soldiers in the trenches that the red flag should be their flag. Okonkwo can also be called a man of great ability as he was:

Cut out for great things. He had won fame while still young as the greatest wrestler in the nine villages. He was a wealthy farmer, had two barns full of yams and had just married his third wife. He had taken two titles and had shown incredible prowess in two inter-tribal wars. (TFA 56) Though Kira Argounova and Leo Kovalensky of We the Living and Ezeulu of Arrow of God have the raw materials for later achievement, none of them in this phase, are allowed to develop those natural resources. Kira has grand aspirations; she wants to be a builder and build bridges and buildings. To that end, she is a good student at the Technological Institute. The readers are convinced that she could be an able engineer but she is prevented from becoming one. She is expelled from the Institute because she is the daughter of a former factory owner. Her talents are buried in a deadening job as an excursion guide. Leo Kovalevsky's only demonstrated talents are in the attraction of women. Though Kira believes in him and though he does begin his studies in the University, his promise is also stultified by the reverse discrimination practiced against children of those who were once in power. Leo's only accomplishments are a bitter bravado and black marketing.

Ezeulu, the Chief Priest of Ulu, tries to regain his power which he feels has been slowly slipping away from his position. Owing to a misunderstanding with Captain Winter bottom, Ezeulu is exiled and jailed for more than a month. By the time he returns, it is time for the New Yam Festival, and only Ezeulu can announce the yearly cycle. But Ezeulu refuses to announce the New Yam Festival and the yams begins to rot in the land, the village enmasse make their sacrifice to the Christian God instead, and the old traditional religion loses its vestiges of power almost overnight. There is a noticeable development seen in the growth of the protagonists in the second books of the very same phase. Ezeulu of Arrow of God is a much more significant than Okonkwo of Things Fall Apart, just as Equality 7-2521 and Liberty 5-3000 of Anthem are much more significant than Kira and Leo of We the Living. The protagonists in Anthem and Arrow of God are characterized by what they do rather than by the lengthy authorial commentaries or description. There is a lot more introspection both in the form of dreams and in conversation that these protagonists indulge in. Ezeulu is as much an enigma as Kira. It is difficult to understand their attitude and actions. Kira Argounova, Leo Kovalensky, Equality 72521, Liberty 5-3000 and Ezeulu are much less gregarious individuals than Okonkwo.

In this phase, Rand also sows the seeds of her concept of a parasitical society. Rand calls her society 'parasitical', as the Communist system does not permit productivity. But Achebe's society is depicted as a 'productive' society, not parasitical or opportunistic like Rand's. Achebe's society on the contrary promotes ability and appreciations men of courage and achievement.

The 'negative characters' like Pavel Syerov and Victor Dunaev are more specifically opportunistic than parasitical. Pavel Syerov and Victor Dunaev in a real sense are feeding off the productivity of others. Pavel Syerov trades upon his supposed friendship with Andrei Taganov, who is a real hero. He also benefits from the dangerous activities of speculators.

Victor Dunaev has some real abilities, but he uses them to further his political aims, not to accomplish anything concrete. But there are not many negative or opportunistic characters in this phase of Achebe's world, unless the white man can be considered so; however Achebe himself declares that the white man's invasion brought its own advantages and disadvantages. Rand places great importance even in this early phase on the love theme, as an instantaneous recognition of a breed apart and sows the seeds of one of her major philosophic premises that 'Love is a response to values'. (AS 987) In Achebe's fiction, in phase I, the love theme is totally missing. This is because the emphasis in Achebe's world, unlike in Rand's is more on communal life rather than on the individual's aspiration. Moreover Things Fall Apart and Arrow of God are situational novels, not novels of character like Rand's We The Living and Anthem. The prime concern of Achebe here is recording the destruction of a traditional culture, and not depicting character, like Rand.

There is a difference in the way Rand and Achebe treat their individuals and their societies. In Rand, the triumph of individuals like Kira Argounova, Andrei Taganov of We the Living; Equality 7-2521 and Liberty 53000 of Anthem symbolize the triumph of the individual and the death of the Communist society. But Achebe's handling of the tragedy of individuals namely Okonkwo of Things Fall Apart and Ezeulu of Arrow of God symbolizes the death and decay of a rich, traditional society, because in this society, and so their fall is also the beginning of things falling apart in the Ibo Society. But in another sense, the emergence of these individuals as independent beings, standing apart from the rest of society, speaks much for them as individuals who did stand alone with nothing and no one else beside them.

Blue Eyes Intelligence Engineering \& Sciences Publication 


\section{The Emergence of The Autonomous Individual}

While Rand depicts her ruthless society as one where no alien force is responsible for freezing the life of the individual Achebe depicts his society on a very compassionate basis and shows how alien forces froze a noble, simple, yet rich poetic way of life.

Unlike in Rand's fiction, Achebe's novels show how Christian missionaries and The British intervene by the end of the nineteenth century and the Ibo society experiences a transitional phase at the socio-cultural, religious and economic levels. Rand's fiction does not depict such a transition; she condemns the political dictatorship that wrenches at the hearts and lives of men and women in a blood-thirsty society.

Even in this first phase, Rand and Achebe's attitude to God and religion stands out in sharp contrast. Joseph Sobran in his article, "Mussolini Shrugged : Ayn Rand Revived", tells us that just as some Christian could only see Communism as Jewish Bolshevism, Rand seems to have thought of Communism as the logical extension of Christianity, for which her euphemizes were 'mysticism' and 'altruism'. (Sobran 1989:53) An atheist herself, she makes no connection between Communism and atheism and never expresses sympathy for Communism Christian victims. "Religion", she writes in her private notebook in 1934 , "is the first enemy of the ability to think... Faith is the worst curse of mankind". Championing the cause of reason, she believes that 'Man as he ought to be' is worthy of worship and hence all her major protagonists are depicted as men who ultimately evolve into 'demi-Gods'. Thus evolves her cult of 'Man-Worship'. Kira Argounova of We The Living and Liberty 5-3000 of Anthem love and worship Leo Kovalensky and Equality 7-2521 to such an extent that they are willing to follow them blindly to the end of the world.

But in Achebe's world, the Ibo society is in direct contact with the supernatural through their various rituals, ceremonies, beliefs, myths and legends, all which one finds missing in Rand's world. Though the type of religion practiced in the Ibo world is primitive, yet it is sincere and honest. There is hardly any life activity from birth to death that is not intimately punctuated by a religious exercise. This traditional Ibo religion is based on the forces and elements of nature, as Dalafosse in his book The Negroes of Africa: History and Culture observes that this type of religion an "agrarian cult". ${ }^{31}$ (Dalafosse 1981:219)

Phase I depicts Rand's doctrine of Objectivism in its embryonic stage. The villains of We The Living The and Anthem are depicted as 'selfish' people; whereas Kira Argounova engages one's sympathy because she loves another so much that she commits a monstrously 'unselfish' act. Kira becomes the mistress of Andrei in order to send her lover Leo to a Tuberculosis sanatorium. True, the concept of selfishness underwent a drastic high redefinition in Rand's hands as Sobran in his article "Mussolini Shrugged" tells us," but it is still stretching a point too far to call Kira 'more' selfish, in any sense, than the grubby little Party worms she has to contend with. She no doubt had more self respect but we didn't need Ayn Rand to point this out to us". 32 (Sobran 1989:53)

Achebe's philosophic concern in these two novels is not very different from those he wrote later. He respects

communal living and the Brotherhood of man and also individual men of courage and achievement. But in Phase I Achebe shows through the tragedies of Okonkwo and Ezeulu, that no man can exist outside his society, and if they do, they pay a high price.

Both Rand and Achebe wrote in the English Language out of choice, as they felt they could express themselves better in English rather than in their own native tongue. But Rand admits, unlike Achebe, she was not fully satisfied with the way she said things in this phase. For example, Rand felt that Kira's reactions to Leo were not quite right, they were too brief and understated. Rand's characters in this phase seem to speak for themselves and not for Rand. Again unlike Achebe, the authorial commentary in this phase is not fully heard; there are numerous examples of authorial commentary heard through oral illustrations and proverbs in Achebe's fiction. The most revealing of these comments is often presented through a second character, reflecting upon another. In such a manner Ezeulu's son, Edogo thinks about his father. The trouble with Ezeulu was that he could never see something and take his eyes away from it. That was what their father could never learn. He must go on treating his grown children like little boys, and if they ever said 'no' there was a big quarrel. This was why the older his children grew the more he seemed to dislike them. ${ }^{33}$ (Achebe 1960:103-104)

Sometimes the oral illustration is related to a more personal desire or need. When released from jail, Ezeulu says:

I cannot stay another day ... I am the tortoise who was trapped in a pit of excrement for two whole markets, but when helpers came to haul him out on the eight day he cried; "QUICK, QUICK: I cannot stand the stench". (AOG 204) The use of these oral examples is a primary means of characterization, and it is the adults in Achebe's novel who make the greatest use of these materials, giving the impression of great wisdom. The majority of the proverbs in Arrow of God are spoken as dialogue rather than as a part of authorial commentary. The unique aspect of Achebe's characterization, then, is the use of oral literary materials. He uses it far more frequently than other African writers.

In the next chapter the researcher traces the growth of individualism in the second phase of he fiction of Ayn Rand and Chinua Achebe. In Rand, the individual is seen evolving from the 'foetus' to the ideal 'man-child' of The Fountainhead; and Achebe's individuals in No Longer at Ease and A Man of The People are seen emerging from a secure solidarity to a new form of 'identity crisis' resulting from their assimilation of the Western culture and their inability to accommodate the two.

\section{REFERENCES}

1. Writing of Ayn Rand

2. We the Living. New York: New American Library, 1936.

3. Anthem. New York: New American Library, 1946.

4. Writings of Chinua Achebe

5. Things Fall Apart. New Delhi: Heinemann, 1975.

6. Arrow of God. London: Heinemann, 1977. 
7. (All textual quotes within the text are taken from these editions)

1. Peikoff, Leonard. "The Totalitarian Universe" ed. The Ominous Parallels. New York: New American Library, 1982:

2. Branden, Barbara in "New Masses", The Passion of Ayn Rand. New York: Doubleday, 1986:71.

3. Ibidem: 77

4. Branden, 1986:78

5. Achebe, Chinua, "The Role of the Writer in a New Nation," Nigerian Magazine, 81 ,June (1964):159.

6. Branden, Barbara, The Passion of Ayn Rand, New York: Doubleday, 1986:101.

7. Wren, Robert, Achebe's World: The Historical and Cultural Context of the Novels of Chinua Achebe. London: 1980:3

8. Ibidem 1980: 15.

9. Baynes, N.H, The Speeches of Adolf Hitler. Boston: Houghton Mifflin, 1922-39.

10. Peikoff, Leonard "Ethics of Evil", The Ominous Parallels, New York: New American Library, 1982: 81.

11. Sobran, Joseph, "Mussolini Shrugged; Ayn Rand Revived", National Review, 1989: 53

12. Ibidem: 1989:52

13. 13 .Hegel, B.W.F. Phenomenology of the Mind. Trans. J.B. Baillic New York: Harper \& Rowe, 967:114.

14. Sobran, Joseph, "Mussolini Shrugged; Ayn Rand Revived", National Review, 1989: 53

15. Gladstein, Mimi. The Ayn Rand Companion: An Analysis of her Fiction. New York: New American Library, 1982:57

16. Ibidem: 57

17. Weber, Max. Sociology of Religion. Tan Parson. London: Scribner, 1930: 45.

18. Achebe, Chinua, "Cultural Events in Africa," New Statesman. 29 March (1967): 11

19. Obiechina, Emmanuel," Culture, Tradition and Society in the West African Novel,” London: Cambridge University Press, 1975: 222.

20. Fromm, Erich, The Sane Society, 1956: 30

21. Ibidem: 38

22. Obiechina, E. Culture, Tradition and Society in the West African Novel. London: Cambridge University Press, 1975: 222.

23. Obiechina, 1975: 224

24. Carroll, David. Chinua Achebe, New York: Twayne, 1980:67

25. Ibidem: 1980:56.

26. Weber, Max., The Protestant Ethic and Spirit and Capitalism. Tan Parson. London: Scribner, 1930 : 59-76

27. Neil McEwen, Africa and the Novel observes two distinct narrative voices: 'traditional-communal,' and the modern individual 1983:22-25

28. Obiechina, Emmanuel, "The Human Dimension of History in Arrow of God," London: Cambridge University Press, 1979:170.

29. Weber, Max., The Protestant Ethic and Spirit and Capitalism. Tan Parson. London: Scribner, $1930: 20-31$.

30. Carroll, David. Chinua Achebe, New York: Twayne, 1980: 90

31. Delafosse, Maurice. The Negroes of Africa: History and Culture: Washington: Associated Publishers, 1981:219

32. Sobran, Joseph, "Mussolini Shrugged; Ayn Rand Revived", National Review, 1989: 53

\section{Author Profile}

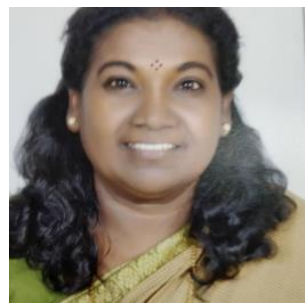

Hyacinth Pink attended graduation and post-graduation at the Madras University; and bagged the 'Gold Medal' for both the M.A. and M. Phil. Degree. Dr. Pink specialized in Comparative Literature, her area of expertise being American and African Literature. He Doctoral dissertation was 'Highly Commended' where she disproved some of the philosophical theories of both these two writers- Ayn Rand and Chinua Achebe. She has successfully guided and produced 7 Doctorates and 34 M.Phil Scholars.

Dr. Pink has a rich varied teaching and research experience of 39 years (1978 till date), where she held responsible portfolios and has carried out her leadership role in a qualitative and innovative manner. She has to her credit 102 research activities. Dr Pink published more than a hundred poems. She is the author of 8 creative Language books and 1 book on Literary Criticism.

Dr. Hyacinth Pink is not only an expert in English Language Teaching and Literature; but also in Journalism and Mass Communication, Creative Writing and was granted 7 UGC sponsored Major \& two Minor projects. Dr.Pink was awarded the State Level Dr. Radhakrishnan Gold Medal Award on Sept $5^{\text {th }} 2016$ for her contribution to research and innovation. 